ROCZNIKI KULTUROZNAWCZE

Tom/Vol. XII, numer/number $2-2021$

DOI: http://doi.org/10.18290/rkult21122-7

\title{
HEALTH ISSUES IN THE GUIDELINES OF CHRISTIAN CHURCHES IN THE CONTEXT OF THE COVID-19 PANDEMIC: TRADITIONS AND INNOVATIONS
}

\section{INTRODUCTION}

In the situation of the COVID-19 pandemic, the efforts of all social groups aimed at eliminating the pandemic and its negative consequences for human health (physical, psychological, spiritual), safety and well-being are very important. Churches, as an important component of society (an authority for a significant part of it), are now looking for ways to respond to the challenges of the day, discussing the need to adhere to orthodox approaches and at the same time to develop appropriate innovations in their activities that would be acceptable rather than heretical. Therefore, it is quite relevant for scholars of religion to study some churches, in particular, the Christian Churches that are widespread in the countries of the Euro-Atlantic circle. Such work has already begun (in Ukraine we have articles by Dmytro Gorevoy, ${ }^{1}$ Victor Yelensky, ${ }^{2}$ Victor Bondarenko, ${ }^{3}$ and Olga Nedavnya. ${ }^{4}$ We have conducted a number of

Olga NedAVNYA - Senior Researcher at the Department of Religious Studies, H. S. Skovoroda Philosophy Institute of the National Academy of Sciences of Ukraine; e-mail: okyjanka@gmail.com; ORCID: https://orcid.org/0000-0003-4634-1137.

${ }^{1}$ Dmytro GoREvoY, “'Ne viryu v koronavirus'. Yak relihiynyy fundamentalizm spryyaye poshyrennyu zakhvoryuvannya na COVID-19? RISU, May 1, 2020, accessed December 31, 2020, www.risu.org.ua/ua/index/monitoring/society_digest/80012.

${ }^{2}$ Victor YELENSKY, "Karantyn ne ye obmezhennyam relihiynykh svobod," RISU, April 18, 2020, accessed December 31, 2020, http://risu.org.ua/ua/index/all_news/state/church_ state_relations/79807.

${ }^{3}$ Victor BonDARENKo, "Koronavirus, tserkva, derzhava i suspilstvo: deyakiaktsentyta vysnovky," RISU, May 3, 2020, accessed December 31, 2020, https://risu.org.ua/ua/index/ blog/ viktor_bondarenko/80029. 
studies on this topic, and we continue to investigate it in this article, as there are still unexplored or insufficiently studied aspects, including theological views on vaccination, the organization of church life during a pandemic, a safe administration of the sacraments, etc. Identifying conservative and innovative (on the verge of adequacy to church doctrine), appropriate approaches is exactly the purpose of this article. To achieve that, the documents and evidence of practical actions of different Churches reflecting the ecclesiastical guidelines for health problems in the context of COVID-19 are analyzed.

However, many more aspects of this topic require scholarly attention. In this article, we aim to identify the most visible manifestations and directions visible in the Christian Churches' search for ways of adapting to the pandemic and understanding the further development of their instructions in the field of health. Therefore, this study seeks to analyze the directives for health problems in the social guidelines and current recommendations of the Christian Churches, to identify relevant conservative and innovative trends, and their proportion in different Churches.

\section{MAIN BODY}

From ancient times to the present day, churches have paid much attention to the issue of health and its preservation. As for the Christian Churches, they all rely on the Bible, which addresses this topic extensively, both in the Old and New Testament. The Old Testament even contains some detailed advice on how to fight various diseases, including infectious diseases, and how to organize quarantine. During the terrible epidemics of the past centuries, the clergy provided both spiritual support and medical care, and traditionally maintained hospitals and hospices. However, they would use treatments which

\footnotetext{
${ }^{4}$ Olga NedAVnYA, "Tserkvy v Ukrayini pid chas epidemiyi kovida-19: zdatnist do zmin ta spivpratsi u yiyi realizatsiyi y potentsiyakh," in Avraamichni relihiyi v Ukrayini v protsesi stabilizatsiyi mizhkonfesiynykh i mizhnatsionalnykh vidnosyn. Mateiraly naukovoyi konferentsiyi: Ukrayina - Vatykan, kontekst mizhkonfesiynykh identychnostey i relihiynykh transformatsiy u sviti ta Ukrayini, 143-50 (Halych: Davniy Halych, 2020); Olga NeDAVNYA, "Vidpovidi Tserkov na vyklyk pandemiyi ta reaktsiya ukrayinskoyi hromadskosti v konteksti problem formuvannya hromadyanskoho suspilstva v Ukrayini," in Problemy formuvannya hromadyanskoho suspilstva $v$ Ukrayini: vyklyky ta koliziyi: materialy Vseukrayinskoyi naukovo-praktychnoyi konferentsiyi (Dnipro, May 15, 2020) (Dnipro: Dnipropetrovsk State University of Internal Affairs, 2020), 69-72.
} 
we would now call superstitious or at least unprovable - from the category of "folk medicine."

It is important to note that the foundations of all social teaching, including those dealing with health, as well as practical guidelines, have been developed in the Churches over the centuries, when the vast majority of people were believers, and for them the issue of salvation was more important than nowadays. This, of course, does not mean that the preservation of the body was ignored, except for some ascetics. However, in disasters such as epidemics of deadly diseases, believers preferred to resort even more to temple religious practices, and meeting with a priest was necessary for the needs of both soul and body (because access to secular doctors was more problematic because they were few). In the pre-secularization, pre-online era, such approaches, of course, were reflected in theological reflections and recommendations.

The Christian Churches have come to the present day with some readymade guidelines on health problems, which are being actively rethought now in the age of advances in modern medicine and communication capabilities. Some Christian Churches which have their own detailed social doctrines Roman Catholic Church (RCC), the Seventh-Day Adventist Church of Ukraine, Russian Orthodox Church (ROC), Ukrainian Orthodox Church (UOC) - have drafted more or less thorough instructions for various cases, others address specific cases by assessing the current situation, giving advice, as well as demonstrating various practical participation. Nowadays, virtually all Churches have to respond to the latest pandemic of COVID-19; in perceiving and responding to this challenge, they show their capabilities and different approaches, both applying their traditional experience and implementing innovations.

When we study the officially approved social doctrines ${ }^{5}$ of those Christian Churches that have them, the following picture emerges. The vast majority of social guidelines on "health issues" contain information about the general

\footnotetext{
${ }^{5}$ Pontifical Council for Justice And Peace, Kompendium sotsialnoyi doktryny tserkvy (Kyiv: KAIROS, 2008); Mykola ZhUKALYUK and Victoria LyUBASHCHENKo, Istoriya Tserkvi khristian Adventistov sedmogo dnya v Ukraine (Kyiv: Dzherelo zhyttya, 2003); RussiAN OrThOdox Church, Osnovy sotsialnoy kontseptsii Russkoy Pravoslavnoy Tserkvy, patriarchia.ru, June 9, 2008, accessed December 31, 2020, http://patriarchia.ru/db/text/419128.html; Orthodox Church of Ukraine, The Social Concept of the Ukrainian Orthodox Church [December 27, 2010] (in Ukrainian), orthodox.org.ua, accessed December 31, 2020, http://www. ortho dox.org.ua/page/sots\%D1\%96alna-kontsepts\%D1\%96ya.
} 
views of the Churches on this topic, abortion, contraception, euthanasia, alcoholism and drug addiction, mental illness, treatment, healthy nutrition (Adventists). Social doctrines, however, rarely mention epidemic diseases, quarantine measures and vaccination, and such mentions are quite concise; the relevant issues are not addressed. Perhaps this is because all these social doctrines were written in the last three decades of the twentieth century, when humanity, at least in developed countries, no longer suffered from major epidemics as devastatingly as in previous ages, and vaccination had been successfully implemented. Some Churches partially fill this gap in their other documents and explanatory materials.

Thus, the RCC in its dictionary of moral theology speaks positively about vaccination. ${ }^{6}$ There is no official document in this Church claiming the contrary. Instead, there are documents that clarify the Church's position on those vaccines for the development of which abortion material was used: "Moral reflections on vaccines prepared from cells derived from aborted human foetuses" of the Pontifical Academy of Life of June 9, 2005 and the "Instruction Dignitas Personae on certain bioethical questions" of the Congregation for the Doctrine of the Faith (paragraphs 34-35) of September 8, 2008, and the "Note on the Italian vaccine problem" of the Pontifical Academy "For Life" (2017), which state that the use of such vaccines is permissible, while emphasizing that believers are obliged to expect the development and implementation of alternative vaccines. ${ }^{7}$

It should be noted that some hierarchs of the RCC outside Ukraine are critical of this approach as leading to actions that are, in their opinion, incompatible with the Church's teaching on abortion. This is stated in the call "On the moral inadmissibility of the use of a vaccine made from cells derived from aborted children" ${ }^{\prime 8}$ of December 12, 2020 by Cardinal Janis Puyats, Metropolitan Emeritus of the Archdiocese of Riga, Archbishop Tomas Pet, Metropolitan of the Archdiocese of the Blessed Virgin Mary in Astana, Archbishop Jan Pavel Leng, Bishop Emeritus of the Diocese of Karaganda,

\footnotetext{
6 “Chy pravda, shcho Tserkva zaboronyala vaktsynatsiyu?" CREDO, October 19, 2018, accessed December 31, 2020, http://credo.pro/2018/10/222253.

7 "Amerykanski yepyskopy: Vaktsyny proty COVID-19 ye 'moralno pryynyatnymy'," CREDO, November 30, 2020, accessed December 31, 2020, https://credo.pro/2020/11/279 759 ? fbclid=iwar0kvhla8b9dkqiv3dmy9fqgz7xmiotojyudjibmzwwjfo8phztbqjirv5v.

${ }^{8}$ KATOLYTSKYY OHLYADACH, "Pro moralnu nedopustymist vykorystannya vaktsyny, vyhotovlenoyi iz klityn, shcho pokhodyat vid abortovanykh ditey," Facebook, December 16, 2020, accessed December 31, 2020. www.facebook.com/catholicnews.org.ua/photos/a.3550987279 $41920 / 3585326641585763$.
} 
Bishop Joseph E. Strickland, Ordinary of the Diocese of Tyler (USA), and Bishop Athanasius Schneider, Auxiliary Bishop of the Archdiocese of the Blessed Virgin Mary. The signatories condemn the use of such vaccines, in particular for COVID-19, as "cooperation with evil" in the form of support for abortion, albeit indirect and remote.

Instead, the American bishops of the RCC precautionarily urged scientists not to use abortion materials in the manufacture of coronavirus vaccines, ${ }^{9}$ and later clarified that the vaccines produced are morally acceptable. ${ }^{10}$

The hierarchs of the RCC in Ukraine did not question the possibility and expediency of using vaccines, but instead focused on reflection on church life during the epidemic, at the level of its organization and the level of individual believers. The relationship between online and offline forms of this life is subject to comprehension and practical proposals, emphasizing both the need to maintain real participation in liturgy, taking into account the appropriate quarantine restrictions (which is the common approach of the RCC and Ukrainian Greek Catholic Church (UGCC) hierarch ${ }^{11}$ ) and innovatively looking for effective remote ways. Theological reflections on the problems of religious consciousness and activity during the pandemic were presented by Cardinal Kurt Koch, ${ }^{12}$ President of the Pontifical Council for Promoting Christian Unity, and Cardinal Robert Vitillo, ${ }^{13}$ a member of the COVID-19 Commission established by Pope Francis. In Ukraine, the need for a relevant interpretation of various theological issues related to the problems of religious and church life in a pandemic was emphasized by the Dominican Fr. Petro Balog. ${ }^{14}$

\footnotetext{
9 "SSHA: yepyskopy zaklykayut ne vykorystovuvaty klityny z til abortovanykh ditey u rozrobtsi vaktsyny vid koronavirusu," CREDO, April 21, 2020, accessed December 31, 2020, http://credo.pro/2020/04/262418.

10 "Amerykanski yepyskopy: Vaktsyny proty COVID-19 ye 'moralno pryynyatnymy'."

11 "Yepyskopy UGKTS ta RKTS zaklykaly vladu ne zakryvaty khramy ta efektyvno vykorystaty koshty na podolannya pandemiyi," RISU, December 9, 2020, accessed December 31, 2020, http://risu.ua/yepiskopi-ugkc-ta-rkc-zaklikali-vladu-ne-zakrivati-hrami-ta-efektivnovikoristati-koshti-na-podolannya-pandemiyi_n114172.

12 "Shcho teolohiya hovoryt pro pandemiyu. Stattya kardynala Kokha," CREDO, June 3, 2020, accessed December 31, 2020, http://credo.pro/2020/06/266267.

13 "Chlen vatykanskoyi komisiyi z Covid-19: pandemiya prymushuye lyudstvo zminytysya," CREDO, November 18, 2020, accessed December 31, 2020, www.credo.pro/2020/ 11/278709.

${ }^{14}$ Petro BALOG, "Virus i prychastya," RISU, March 13, 2020, accessed December 31, 2020, http://risu.org.ua/ua/index/blog/ Petro+Balog/79227.
} 
The year of COVID-19 became for Catholics a year of initially encouraged and then strongly recommended ${ }^{15}$ online participation in worship services. The same was done in the Orthodox Church of Ukraine (OCU) ${ }^{16}$ However, for the RCC and the UGCC, the remote participation of believers in services has been not new for a long time: before the emergence of the Internet, Catholic believers, including UGCC underground members, listened to liturgies on Vatican Radio. Nowadays, Pope Francis has set an example of further innovations in the liturgical sphere and communication with believers, and he has called on scientists to develop a coronavirus vaccine as soon as possible, emphasizing the need to make it accessible to all, including the most vulnerable segments of the population. ${ }^{17}$ And when these vaccines were already produced, the Holy See's Congregation for the Doctrine of the Faith delivered its verdict: they are morally acceptable; moreover, those who refuse to be vaccinated on the grounds of conscience are obliged not to become a source of disease for others. ${ }^{18}$

Pope Francis's attitude is shared by the UGCC head, His Beatitude Sviatoslav, who emphasized that the vaccine would really help to protect people's lives and health. ${ }^{19}$ The workers of the School of Bioethics of the Ukrainian Catholic University (UCU) explain that the Church tolerates a vaccine in the development of which aborted materials were used as long as there is no alternative, and claims the advantage of alternative ones. ${ }^{20}$ Regard-

\footnotetext{
15 "Rymo-katolyky v Ukrayini zvilneni vid uchasti u nedilniy Mesi," CREDO, March 17, 2020, accessed December 31, 2020, https://credo.pro/2020/03/259015?fbclid=IwAR0r_vHm 72L9DoDgpYzH9y625SKnME0gwmPRAyCXnawwy63eVepnMMsB9g.

${ }^{16}$ Orthodox Church of UKRAINe, "Rishennya Svyashchennoho Synodu vid 24 bereznya 2020 r.," pomisna.info, March 24, 2020, accessed December 31, 2020, www.pomisna.info/uk/ document-post/povidomlennya-pro-rishennya-svyashhennogo-synodu/?fbclid=IwAR0D_CPU HMy-5BumA78I7BSR_IhCVqIOiw1wuJHFDDOEqDdxKBTOaRUuLNU.

17 "Papa zaklykav uchenykh znayty yaknayshvydshe vaktsynu vid Covid-19 i ozvuchyv datu zahalnoyi molytvy za poryatunok," RISU, May 4, 2020, accessed December 31, 2020, http://risu.ua/papa-zaklikav-uchenih-znayti-yaknayshvidshe-vakcinu-vid-covid-19-i-ozvuchivdatu-zagalnoji-molitvi-za-poryatunok_n104307.

${ }^{18}$ COngregation for the Doctrine of THE FAith, "Note on the morality of using some anti-Covid-19 vaccines," vatican.va, December 21, 2020, https://www.vatican.va/roman_curia/ congregations/cfaith/documents/rc_con_cfaith_doc_20201221_nota-vaccini-anticovid_en.html.

19 "Do vaktsyny vid Covid-19 povynni maty dostup i sotsialno nezakhyshcheni lyudy, - Hlava UGKTS," RISU, November 21, 2020, accessed December 31, 2020, https://risu.ua/do-vakcini-vidcovid-19-povinni-mati-dostup-i-socialno-nezahishcheni-lyudi---glava-ugkc_n113 657.

20 "Vaktsyny, vyhotovleni na liniyi embrionalnykh klityn: mozhna chy ne mozhna vzhyvaty?" UCU School of Bioethics, March 6, 2019, accessed December 31, 2020, http://bioethics.ucu.edu.ua /vaktsyny-vygotovleni-na-lyudskyh-biomaterialah-mozhna-chy-ne-mozhna-vzhyvaty.
} 
ing the vaccine against COVID-19, UCU adopted a special address which highlights its positive official attitude towards it, and emphasizes that a possible different opinion of some employees of the University does not reflect this attitude. The address emphasizes: "As a higher education institution, UCU is called to form and disseminate knowledge and help Ukrainian society navigate difficult life situations and evaluate information on the basis of scientific evidence, verified facts and arguments. As an institution founded by the Church, we cultivate an atmosphere of faith and sincere daily prayer, not superstitions and prejudices. In long-term collaboration with the United Nations Children's Fund (UNICEF) and the United States Agency for International Development (USAID), our university has the opportunity to teach priests, government officials, physicians, and secular people how to counter vaccination myths, build quality communication, manage health care institutions, and take care of life and human health." 21

The head of the UGCC also reflects on various theological aspects in assessing the situation caused by the pandemic, in the life of the Church, the people, individual families and individuals. He emphasizes that everyone had to change, and the Church in particular, and that the pandemic had not only purely medical but also economic and political consequences, that it became a new challenge for the Church and the world. "The UGCC experienced a crisis of its identity.... The pandemic struck the very heart of the Church, because priests were forced to urge people not to come to churches. Priests have learned to communicate in a new way with the faithful. We have all learned to work and communicate online. To listen, understand, help and organize events online. We have learned to feel like members of the global Church in a new way. We have also learned to uphold the rights of the Church, to hold services in a pandemic in compliance with all sanitary norms, proving to the state that the Church is not a dangerous place for infection.... And the state finally believed that the Church is a partner in achieving new standards of human health." 22

\footnotetext{
21 “Zvernennya rektoratu z pryvodu pandemiyi COVID-19," Ukrainian Catholic University (Rector's address, December 8, 2020), accessed December 8, 2020, accessed December 31, 2020, http://ucu.edu.ua/ news/zvernennya-re ktoratu-z-pryvodu-pandemiyi-covid-19.

22 “2020 rik - tse 'kovidnyy' rik, v yakyy Tserkva navchylasya zhyty po-novomu, - Hlava UHKTS na Zhyvomu TB," RISU, December 16, 2020, accessed December 31, 2020, http:// risu.ua/2020-rik---ce-kovidnij-rik-v-yakij-cerkva-navchilasya-zhiti-po-novomu---glava-ugkcnazhivomu-tbn 114413.
} 
Among the Protestant Churches, a comprehensive social doctrine was developed by the Seventh-Day Adventist Church, and much attention was paid to the issues of health and its preservation in the Fundamentals of Social Doctrine $^{23}$ of this Church. The fundamental points of the statement are also made from the traditional prudent standpoint, but Adventists, like Catholics, supplement their guidelines with modern scientific, medical knowledge, and today's realities of life. These guidelines emphasize the need for disease prevention and sanitation, yet do not specifically address the issues of epidemics and vaccination.

However, the approach of Ukraine's Seventh-Day Adventist Church to vaccination is clear on its official website: it is strongly endorsed. As in the UGCC (UCU), it is emphasized that the refusal of individual Adventists to get vaccinated is incorrect and unsubstantiated by Adventist teaching. ${ }^{24}$ Today, Adventists in Ukraine are actively campaigning for vaccination in the COVID-19 pandemic. The website of the Seventh-day Adventist Church in Ukraine published an article "Why immunization is more important now than ever." 25

Other Protestant Churches, which do not currently have their own official social doctrines, have also demonstrated and promoted a similar attitude towards health and vaccination issues, in particular by highlighting positive assessments by a number of Protestant Churches operating in Ukraine and other countries. ${ }^{26}$ Like the Catholic Churches, Protestants have no problem using online worship. Issue no. 4 (2020) of the magazine of Ukrainian Pentecostals Blagovisnyk was devoted to the issue of physical health during the pandemic, in particular, its connection with spiritual health. ${ }^{27}$ The website of the Ukrainian Church of Christians of the Evangelical Faith considered it appropriate to post a specific practical explanation who can be vaccinated

\footnotetext{
${ }^{23}$ ZHUKALYUK and LyUBASHCHENKO, Istoriya Tserkvi khristian Adventistov sedmogo dnya $v$ Ukraine.

${ }^{24}$ Seventh-Day Adventist Church, "Vidmova vid shcheplen i Adventystska tserkva," adventist.ua, accessed December 31, 2020, www.adventist.ua/news/analytics/otkaz-ot-pryvyv ok-y-adventystskaya-tserkov.

${ }^{25}$ SEVEnTH-DAy AdVEnTist Church, "Chomu imunizatsiya zaraz vazhlyvisha, nizh budkoly," adventist.ua, accessed December 31, 2020, http://adventist.ua/news/world/chomu-imu nizaciya-zaraz-vazhlivisha-nizh-bud-koli.

${ }^{26}$ Aleksandr ShevchenKo, "Vaktsinatsiya: vzglyad tserkvi" (Online Forum), YouTube, accessed 31 December 2020, https://www.youtube.com/watch?v=Ug-VCwKsxHg.

${ }^{27}$ Ukrainian Church OF Christians of THE EvangelicAl FAith, "Turbota pro zdorovya: balans viry ta zusyl - tema zhurnalu 'Blahovisnyk'," Chwe.org.ua, December 17, 2020.
} 
against COVID-19 at the state's cost. ${ }^{28}$ The above-mentioned resource of the Ukrainian Pentecostals contains other recommendations for action in the context of the epidemic, aimed at preserving human health. The website of the All-Ukrainian Union of Evangelical Baptist Churches recommends a large informative resource "Church and Quarantine," 29 the result of the creative work of the church, a truly "Klondike" of useful information, innovative reflections and constructive examples of how to care for health, also spiritual one, during a pandemic. Theological reflections on conservative and innovative approaches to spiritual problems in such conditions were published in the Baptist magazine Bogomyslie by a group of teachers of the Odessa Theological Seminary. ${ }^{30}$

In the Orthodox Churches there is a large diversity of attitudes to COVID19 problems, and extremely conservative emphases and innovative approaches may occur within the same Church: both in terms of permissible changes in liturgical and sacramental, and in forms of quarantine restrictions. The Russian Orthodox Church in the Fundamentals of its social concept does not rule out the possibility of using modern medical advances to maintain the health of believers, although quarantine measures or vaccination are not even mentioned there. The same applies to the UOC Social Concept, which is not very different to the previous one. The head of the ROC, Patriarch Kirill, has now avoided specifying the attitude to the coronavirus vaccine. His current position was voiced by Vakhtang Kipshidze, Deputy Head of the Synodal Department for Interaction of the ROC with the Mass Media: "Until the coronavirus vaccine passes all clinical trials, the question of whether His Holiness will be vaccinated and declare it publicly is not relevant." 31

In Ukraine, the attitude of UOC clergy regarding possible changes in liturgical activities and church attendance, as well as regarding vaccination, appears to be different. At the beginning of the quarantine declared in our

\footnotetext{
28 "Khto pidlyahaye bezkoshtovnomu testuvannyu na COVID-19 - konsultatsiya yurysta," chve.org.ua, August 21, 2020, accessed December 31, 2020, www.chve.org.ua/covid-19_testu.

29 “Tserkva i karantyn," For Church, accessed December 31, 2020, http://forchurch .info/tserkva-i-karantyn.

${ }^{30}$ Igor BANDURA et al., "COVID-10 i paskha onlayn v umovakh karantinu," Bogomysliye, no. 26 (2020): 35-48.

31 Yevgeniy SAFronOv, "Patriarkh Kirill ne budet privivat'sya ot koronavirusa, poka vaktsina ne proydot vse klinicheskiye ispytaniya," Open Media, September 4, 2020, accessed December 31, 2020, www.openmedia.io/news/n2/patriarx-kirill-ne-budet-privivatsya-ot-koro navi rusa-poka-vakcina-ne-projdet-vse-klinicheskie-ispytaniya.
} 
state, this Church prepared a rather moderate address, ${ }^{32}$ which recognizes the appropriate sanitary restrictions and identifies certain changes in the reception of certain sacraments. So far, there have been only situational reactions to vaccination. Thus in 2019, during the outbreak of measles in our country, Metropolitan Agafangel of Odessa forbade the clergy of his diocese to convince parents not to vaccinate their children. ${ }^{33}$ Instead, in that "crazy" year, the prior of the Pochaiv Lavra, following the Synod of the Moldovan metropolitanate of the ROC, ${ }^{34}$ criticized Bill Gates for his plans for a coronavirus vaccine as a means of chipping people. ${ }^{35}$ On October 2, 2020, a priest of the UOC in front of the Ukrainian Parliament building campaigned against vaccinations, arguing that it was false information about vaccines. ${ }^{36}$ It should be noted that among the believers of this Church there are unofficial movements that have always claimed that vaccines are completely incompatible with the Church's instructions as tools of the devil, Freemasons or the "world government" designed to chip people to establish totalitarian control over all mankind. These and other warnings about "the Beast's Seal" can be seen now and then in streets on leaflets designed by such activists.

The Orthodox Church of Ukraine has also adopted Practical Guidelines for the COVID-19 Coronavirus Pandemic at the beginning of the quarantine in Ukraine, supplemented in accordance with the decisions of the Holy Synod of

${ }^{32}$ Orthodox Church of Ukraine, “Zvernennya Svyashchennoho Synodu UPTS u zvyazku z poshyrennyam koronavirusu COVID-19," news.church.ua, March 18, 2020, accessed December 31, 2020, https://news.church.ua/2020/03/18/zvernennya-svyashhennogo-sinoduupc-u-zvyazku-z-poshirennyam-koronavirusu-covid-19.

33 "Svyashchenykam Odeskoyi yeparkhiyi UPTS (MP) zaboronyly ahituvaty proty shcheplen," RISU,January 16, 2018, accessed December 31, 2020, http://risu.ua/cvyashcheni kam-odeskoji-yeparhiji-upc-mp-zaboronili-agituvati-proti-shcheplen_n88699.

34 "Moldovska mytropoliya RPTS zvynuvatyla Billa Geytsa u stvorenni tekhnolohiyi mikrochipuvannya, yaku zastosovuvatymut pry vaktsynats," RISU, May 21, 2020, accessed 31 December 2020, http://risu.ua/moldovska-mitropoliya-rpc-zvinuvatila-billa-geytsa-u-stvorennitehnologiji-mikrochipuvannya-yaku-zastosovuvatimut-pri-vakcinaciji_n104634.

${ }^{35}$ Viktoriya BEGA, "Namestnik Pochayevskoy lavry schitayet, chto Bill Geyts ispolzuyet vaktsinu ot koronavirusa, chtoby chipirovat lyudey," Hromadske, June 1, 2020, accessed December 31, 2020, www.hromadske.ua/ru/posts/namestnik-pochaevskoj-lavry-schitaet-chtobill-gejts-ispolzuet-vakcinu-ot-koronavirusa-chtoby-chipirovat-lyudej.

36 "Svyashchenyk UPTS MP ahituvav pid VRU proty shcheplen, ID-pasportiv ta za sproshchenyy peretyn kordonu z Rosiyeyu," RISU, October 2, 2020, accessed 31 December 2020, http://risu.ua/svyashchenik-upc-mp-agituvav-pid-vruproti-shcheplen-id-pasportiv-ta-zasproshchenij-peretin-kordonu-z-rosiyeyu_n112303. 
March 24, 2020 and April 9, 2020. ${ }^{37}$ In comparison with the UOC address, these Practical Guidelines substantiate in more detail the theological statements of the OCU's consent to quarantine restrictions and its reasoning regarding the proper behavior of believers during the pandemic. Temples are allowed to be closed (if quarantine rules cannot be observed), lay people are even asked to stay at home, joining the common prayer online. Also, some changes in forms of carrying out of sacraments and ceremonial actions are defined, the general confession is allowed. Looking for advice about possible forms of Communion, the Church wrote a letter to the Patriarch of Constantinople. $^{38}$

The OCU is generally in favor of vaccination, as evidenced by its Primate Epiphanius, who assured of its support for immunization and information about the importance of vaccination in Ukraine (this was discussed, in particular, at last year's meeting of the Heads of the Church and the Ministry of Health of Ukraine $^{39}$ ). He now spoke in favor of vaccination against COVID-19, emphasizing that the Church was going to carry out appropriate explanatory work and was hoping to obtain the vaccine under the state program for their own clergy ${ }^{40}$ ).

\section{CONCLUSIONS}

Thus, an analysis of the guidelines of the Christian Churches (particularly in Ukraine and other countries of Euro-Atlantic zone) on health issues reveals an interrelation between more orthodox approaches and the innovative ones to

\footnotetext{
37 ORTHOdox ChURCh OF UKRAINE, "Praktychni nastanovy u zvyazku z pandemiyeyu koronavirusnoyi khvoroby COVID-19 dopovneni vidpovidno do rishen Svyashchennoho Synodu vid 24 bereznya 2020 roku ta 9 kvitnya 2020 roku," pomisna.info, March 17, 2020, accessed December 31, 2020, http://pomisna.info/uk/document-post/praktychni-nastanovydlya-yepyskopatu-duhovenstva-i-virnyh-u-zv-yazku-z-ogoloshenoyu-pandemiyeyu-osoblyvonebezpechnoyi-koronavirusnoyi-hvoroby-covid-19.

${ }^{38}$ ORTHODOX ChURCh OF UKRAINE, "Zhurnaly zasidannya Svyashchennoho Synodu vid 9 lypnya 2020 r.," pomisno.info, July 10, 2020, accessed December 31, 2020, www. pomisna. nfo/uk/document-post/zhurnaly-zasidannya-svyashhennogo-synodu-vid-9-lypnya-2020-r.

39 "Pravoslavna Tserkva Ukrayiny pidtrymuye vaktsynatsiyu," RISU, August 5, 2019, accessed December 31, 2020, http://risu.ua/pravoslavna-cerkva-ukrajini-pidtrimuye-vakcina ciyu_n99510.

$4 \overline{0}$ "Predstoyatel PTSU: Tserkva pidtrymuye vaktsynuvannya vid COVID-19," RISU, December 23, 2020, accessed December 31, 2020, http://risu.ua/predstoyatel-pcu-cerkvapidtrimuye-vakcinuvannya-vid-covid-19_n114573.
} 
the consideration and recommended solutions to the challenges associated with the COVID-19 pandemic. The part of clergy and laity who in different Churches consider innovative approaches incompatible with Christian teaching is the most noticeable among the Orthodox (in Ukraine among the UOC), and the least among Protestants (in Ukraine, but also in the RCC and UGCC). These approaches - new or refined proposals in the Churches' guidelines are aimed at preserving health and lives of people in this world, but also emphasize the spiritual qualities of empathy, helping others, mutual understanding, charity, and solidarity, which are all important for Christians in terms of their understanding of eternal life. However, in the current situation all Churches will have to refine their social guidelines in the light of new realities, aligning their innovations with fundamental orthodoxy so that they do not seem heretical, at least among the Churches that develop these innovations. Scholars of religion can probably expect a lot of interesting research in this field: in particular, the comparison of relevant work in different Churches, the direction and scale of innovations in individual Churches, the willingness to accept such innovations by ordinary believers, and others.

\section{BIBLIOGRAPHY}

“2020 rik - tse 'kovidnyy' rik, v yakyy Tserkva navchylasya zhyty po-novomu, - Hlava UHKTS na Zhyvomu TB | 2020 рік - це "ковідний' рік, в який Церква навчилася жити по-новому, - Глава УГКЦ на Живому ТБ.” RISU, December 16, 2020. Accessed December 31, 2020. http://risu.ua/2020-rik---ce-kovidnij-rik-v-yakij-cerkvanavchilasya-zhiti-po-novomu---glava-ugkcna-zhivomu-tb_n114413.

"Amerykanski yepyskopy: Vaktsyny proty COVID-19 ye 'moralno pryynyatnymy' | Американські єпископи: вакцини проти COVID-19 є «морально прийнятними»." CREDO, November 30, 2020. Accessed December 31, 2020. https://credo.pro/2020/ 11/279759?fbclid=iwar0kvhla8b9dkqiv3dmy9fqgz7xmiotojyudjibmzwwjfo8phztbqjirv5 v4 [Translation of "Use of Pfizer, Moderna COVID-19 vaccines is morally acceptable, say bishops" by Julie Asher, National Catholic Reporter, November 25, 2020].

BALOG, Petro | Балог, Петро. "Virus i prychastya | Bipyc і причастя." RISU, March 13, 2020. Accessed December 31, 2020. http://risu.org.ua/ua/index/blog/ Petro+Balog/79227.

BANDURA, Igor, Anatoliy BondARenKo, Aleksandr Geychenko, Sergey SANNIKov, Vitaliy STANKEVICH, and Fedor StRIZHACHUK. "COVID-10 i paskha onlayn v umovakh karantinu.” Bogomysliye, no. 26 (2020): 35-48 | Бандура, Игорь, Анатолий Бондаренко, Александр Гейченко, Сергей Санников, Виталий Станкевич, Федор Стрижачук. «COVID-19 і пасха онлайн в умовах карантину». Богомыслие, № 26 (2020): с. 35-48. Accessed December 31, 2020. http://almanah.bogomysliye.com/article/view/ 202840. 
BEGA, Viktoriya | Бега, Виктория. "Namestnik Pochayevskoy lavry schitayet, chto Bill Geyts ispolzuyet vaktsinu ot koronavirusa, chtoby chipirovat lyudey | Наместник Почаевской лавры считает, что Билл Гейтс использует вакцину от коронавируса, чтобы чипировать людей." Hromadske, June 1, 2020. Accessed December 31, 2020. www.hromadske. ua/ru/posts/namestnik-pochaevskoj-lavry-schitaet-chto-bill-gejts-ispolzuet-vakcinu-otkoronavirusa-chtoby-chipirovat-lyudej.

BONDARENKO, Victor | Бондаренко, Віктор. "Koronavirus, tserkva, derzhava i suspilstvo: deyaki aktsenty ta vysnovky | Коронавірус, церква, держава і суспільство: деякі акценти та висновки." RISU, May 3, 2020. Accessed December 31, 2020. https://risu.org.ua/ua/index/blog/ viktor_bondarenko/80029.

"Chlen vatykanskoyi komisiyi z Covid-19: pandemiya prymushuye lyudstvo zminytysya | Член ватиканської комісії з Covid-19: пандемія примушуе людство змінитися." CREDO, November 18, 2020. Accessed December 31, 2020. www.credo.pro/ 2020/11/278709.

“Chy pravda, shcho Tserkva zaboronyala vaktsynatsiyu? | Чи правда, що Церква забороняла вакцинацію?” CREDO, October 19, 2018. Accessed December 31, 2020. http://credo. pro/2018/10/222253.

Congregation for the Doctrine of the Faith. "Note on the morality of using some antiCovid-19 vaccines." vatican.va, December 21, 2020. https://www.vatican.va/ro man_cu ria/congregations/cfaith/documents/rc_con_cfaith_doc_20201221_nota-vaccini-antico vid_en.html.

"Do vaktsyny vid Covid-19 povynni maty dostup i sotsialno nezakhyshcheni lyudy, - Hlava UGKTS | До вакцини від Covid-19 повинні мати доступ і соціально незахищені люди, - Глава УГКЦ.” RISU, November 21, 2020. Accessed December 31, 2020. https://risu.ua/do-vakcini-vid-covid-19-povinni-mati-dostup-i-socialno-nezahishchenilyudi---glava-ugkc_n113657.

Gorevoy, Dmytro | Горєвой, Дмитро. “NNe viryu v koronavirus'. Yak relihiynyy fundamentalizm spryyaye poshyrennyu zakhvoryuvannya na COVID-19? | «Не вірю в коронавірус». Як релігійний фундаменталізм сприяє поширенню захворювання на COVID-19?" RISU, May 1, 2020. Accessed December 31, 2020.www.risu.org.ua/ua/ index/monitoring/society_digest/80012.

KATOLYTSKYY OHLYADACH. "Pro moralnu nedopustymist vykorystannya vaktsyny, vyhotovlenoyi iz klityn, shcho pokhodyat vid abortovanykh ditey | Про моральну недопустимість використання вакцини, виготовленої із клітин, що походять від абортованих дітей." Facebook, December 16, 2020. Accessed December 31, 2020. www.face book.com/catholicnews.org.ua/photos/a.355098727941920/3585326641585763.

"Moldovska mytropoliya RPTS zvynuvatyla Billa Geytsa u stvorenni tekhnolohiyi mikrochipuvannya, yaku zastosovuvatymut pry vaktsynats | Молдовська митрополія РПЦ звинуватила Білла Гейтса у створенні технології мікрочіпування, яку застосовуватимуть при вакцинаці.” RISU, May 21, 2020. Accessed 31 December 2020. http://risu.ua/moldovska-mitropoliya-rpc-zvinuvatila-billa-geytsa-u-stvorenni-tehnolo giji-mikrochipuvannya-yaku-zastosovuvatimut-pri-vakcinaciji_n104634.

NEDAVNYA, Olga. "Tserkvy v Ukrayini pid chas epidemiyi kovida-19: zdatnist do zmin ta spivpratsi u yiyi realizatsiyi y potentsiyakh." In Avraamichni relihiyi $v$ Ukrayini v protsesi stabilizatsiyi mizhkonfesiynykh i mizhnatsionalnykh vidnosyn. Mateiraly naukovoyi konferentsiyi: Ukrayina - Vatykan, kontekst mizhkonfesiynykh identychnostey i relihiynykh transformatsiy u sviti ta Ukrayini, 143-50. Halych: Davniy Halych, 2020 | 
Недавня, Ольга. «Церкви в Україні під час епідемії ковіда-19: здатність до змін та співпраці у її реалізації й потенціях». В Авраамічні релігії в Україні в прочесі стабілізації міжконфесійних $і$ міжнаціональних відносин. Матеірали наукової конферениії: Україна - Ватикан, контекст міжконфесійних ідентичностей і релігійних трансформацій у світі та Украӥні, с. 143-150. Галич: Давній Галич, 2020.

NEDAVNYA, Olga. "Vidpovidi Tserkov na vyklyk pandemiyi ta reaktsiya ukrayinskoyi hromadskosti v konteksti problem formuvannya hromadyanskoho suspilstva v Ukrayini." In Problemy formuvannya hromadyanskoho suspilstva $v$ Ukrayini: vyklyky ta koliziyi: materialy Vseukrayinskoyi naukovo-praktychnoyi konferentsiyi (Dnipro, May 15, 2020), 69-72. Dnipro: Dnipropetrovsk State University of Internal Affairs, 2020 | Недавня, Ольга Володимирівна. «Відповіді Церков на виклик пандемії та реакція української громадськості в контексті проблем формування громадянського суспільства в Україні». В Проблеми формування громадянського суспільства в Україні: виклики та колізії: матеріали Всеукраӥнської науково-практичної конференції (Дніпро, 15 травня 2020 р.), с. 69-72. Дніпро: Дніпропетровський державний університет внутрішніх справ, 2020.

ORTHOdOX ChURCh OF UKRAINE. "Praktychni nastanovy u zvyazku z pandemiyeyu koronavirusnoyi khvoroby COVID-19 dopovneni vidpovidno do rishen Svyashchennoho Synodu vid 24 bereznya 2020 roku ta 9 kvitnya 2020 roku | Практичні настанови узв'язку 3 пандемією коронавірусної хвороби COVID-19 доповнені відповідно до рішень Священного Синоду від 24 березня 2020 року та 9 квітня 2020 року.” pomisna.info, March 17, 2020. Accessed December 31, 2020. http://pomisna.info/uk/document-post/ praktychni-nastanovy-dlya-yepyskopatu-duhovenstva-i-virnyh-u-zv-yazku-z-ogolosheno yu-pandemiyeyu-osoblyvo-nebezpechnoyi-koronavirusnoyi-hvoroby-covid-19.

Orthodox Church of Ukraine. "Rishennya Svyashchennoho Synodu vid 24 bereznya 2020 r. | Рішення Священного Синоду від 24 березня 2020 p.” pomisna.info, March 24, 2020. Accessed December 31, 2020. www.pomisna.info/uk/document-post/povidom lennya-pro-rishennya-svyashhennogo-synodu/?fbclid=IwAR0D_CPUHMy-5BumA78I7 BSR_IhCVqIOiw1wuJHFDDOEqDdxKBTOaRUuLNU.

Orthodox Church of Ukraine. The Social Concept of the Ukrainian Orthodox Church [December 27, 2010] (in Ukrainian). orthodox.org.ua. Accessed December 31, 2020. www.orthodox.org.ua/page/sots\%D1\%96alna-kontsepts\%D1\%96ya.

ORTHOdOX ChURCh OF UKRAINe. "Zhurnaly zasidannya Svyashchennoho Synodu vid 9 lypnya 2020 r. | Журнали засідання Священного Синоду від 9 липня 2020 p.” pomisno.info, July 10, 2020. Accessed December 31, 2020. www.pomisna.info/uk/documentpost/zhurnaly-zasidannya-svyashhennogo-synodu-vid-9-lypnya-2020-r.

Orthodox ChURCh OF UKRAINE. "Zvernennya Svyashchennoho Synodu UPTS u zvyazku z poshyrennyam koronavirusu COVID-19 | Звернення Священного Синоду УПЦ у звязку 3 поширенням коронавірусу COVID-19.” news.church.ua, March 18, 2020. Accessed December 31, 2020. https://news.church.ua/2020/03/18/zvernennya-svyashhennogosinodu-upc-u-zvyazku-z-poshirennyam-koronavirusu-covid-19.

"Papa zaklykav uchenykh znayty yaknayshvydshe vaktsynu vid Covid-19 i ozvuchyv datu zahalnoyi molytvy za poryatunok | Папа закликав учених знайти якнайшвидше вакцину від Covid-19 і озвучив дату загальної молитви за порятунок.” RISU, May 4, 2020. Accessed December 31, 2020. http://risu.ua/papa-zaklikav-uchenih-znayti-yakna yshvidshevakcinu-vid-covid-19-i-ozvuchiv-datu-zagalnoji-molitvi-za-poryatu nok_n104307. 
Pontifical Council for Justice And PeACE. Kompendium sotsialnoyi doktryny tserkvy. Kyiv: KAIROS, 2008 | Папська рада «справедливість і мир». Компендіум соиіальної доктрини иеркви. Київ: КАЙРОС, 2008.

"Pravoslavna Tserkva Ukrayiny pidtrymuye vaktsynatsiyu | Православна Церква України підтримує вакцинацію.” RISU, August 5, 2019. Accessed December 31, 2020. http://risu.ua/pravoslavna-cerkva-ukrajini-pidtrimuye-vakcinaciyu_n99510.

"Predstoyatel PTSU: Tserkva pidtrymuye vaktsynuvannya vid COVID-19 | Предстоятель ПЦУ: Церква підтримує вакцинування від COVID-19.” RISU, December 23, 2020. Accessed December 31, 2020. http://risu.ua/predstoyatel-pcu-cerkva-pidtrimuyevakcinuvannya-vid-covid-19_n114573.

Russian ORTHODOX CHURCH. Osnovy sotsialnoy kontseptsii Russkoy Pravoslavnoy Tserkvi | Основы социальной концепции Русской Православной Церкви. patriarchia.ru, June 9, 2008. Accessed December 31, 2020. http://patriarchia.ru/db/text/419128.html.

"Rymo-katolyky v Ukrayini zvilneni vid uchasti u nedilniy Mesi | Римо-католики в Україні звільнені від участі у недільній Месі." CREDO, March 17, 2020. Accessed December 31, 2020. https://credo.pro/2020/03/259015?fbclid=IwAR0r_vHm_72L9Do DgpYzH9y625SKnME0gwmPRAyCXnawwy63eVepnMMsB9g.

SAFronov, Yevgeniy | Сафронов, Евгений. "Patriarkh Kirill ne budet privivat'sya ot koronavirusa, poka vaktsina ne proydot vse klinicheskiye ispytaniya | Патриарх Кирилл не будет прививаться от коронавируса, пока вакцина не пройдёт все клинические испытания." Open Media, September 4, 2020. Accessed December 31, 2020. www.openmedia.io/news/n2/patriarx-kirill-ne-budet-privivatsya-ot-koronavirusa-pokavakcina-ne-projdet-vse-klinicheskie-ispytaniya.

Seventh-Day Adventist Church. "Chomu imunizatsiya zaraz vazhlyvisha, nizh bud-koly | Чому імунізація зараз важливіша, ніж будь-коли.” adventist.ua. Accessed December 31, 2020. http://adventist.ua/news/world/chomu-imunizaciya-zaraz-vazhlivisha-nizhbud-koli.

Seventh-Day Adventist Church. "Vidmova vid shcheplen i Adventystska tserkva | Відмова від щеплень і Адвентистська церква.” adventist.ua. Accessed December 31, 2020. www.adventist.ua/news/analytics/otkaz-ot-pryvyvok-y-adventystskaya-tserkov.

"SSHA: yepyskopy zaklykayut ne vykorystovuvaty klityny z til abortovanykh ditey u rozrobtsi vaktsyny vid koronavirusu | США: єпископи закликають не використовувати клітини 3 тіл абортованих дітей у розробці вакцини від коронавірусу." CREDO, April 21, 2020. Accessed December 31, 2020. http://credo.pro/2020/04/262418.

"Shcho teolohiya hovoryt pro pandemiyu. Stattya kardynala Kokha | Що теологія говорить про пандемію. Стаття кардинала Коха.” CREDO, June 3, 2020. Accessed December 31, 2020. http://credo.pro/2020/06/266267.

SHEvcheNKO, Aleksandr | Шевченко, Александр. "Vaktsinatsiya: vzglyad tserkvi | Вакцинация: взгляд церкви" (Online Forum). YоuTube. Accessed 31 December 2020. https://www.youtube.com/watch?v=Ug-VCwKsxHg.

"Svyashchenykam Odeskoyi yeparkhiyi UPTS (MP) zaboronyly ahituvaty proty shcheplen | Священикам Одеської єпархії УПЦ (МП) заборонили агітувати проти щеплень.” RISU, January 16, 2018. Accessed December 31, 2020. http://risu.ua/cvyashchenikamodeskoji-yeparhiji-upc-mp-zaboronili-agituvati-proti-shcheplen_n88699.

"Svyashchenyk UPTS MP ahituvav pid VRU proty shcheplen, ID-pasportiv ta za sproshchenyy peretyn kordonu z Rosiyeyu | Священик УПЦ МП агітував під ВРУ проти щеплень, ID- 
паспортів та за спрощений перетин кордону з Росією.” RISU, October 2, 2020. Accessed 31 December 2020. http://risu.ua/svyashchenik-upc-mp-agituvav-pid-vruproti-shcheplen-idpasportiv-ta-za-sproshchenij-peretin-kordonu-z-rosiyeyu_n112303.

“Tserkva i karantyn | Церква і карантин.” For Church. Accessed December 31, 2020. http://forchurch.info/tserkva-i-karantyn.

Ukrainian Church OF Christians OF the Evangelical Faith. "Khto pidlyahaye bezkoshtovnomu testuvannyu na COVID-19 - konsultatsiya yurysta | Хто підлягає безкоштовному тестуванню на COVID-19 - консультація юриста.” chve.org.ua, August 21, 2020. Accessed December 31, 2020. www.chve.org.ua/covid-19_testu.

UKrainian ChURCh OF Christians of the EvangEliCAl FAith | Українська Церква Християн Віри Свангельської. "Turbota pro zdorovya: balans viry ta zusyl - tema zhurnalu 'Blahovisnyk' | Турбота про здоров'я: баланс віри та зусиль - тема журналу «Благовісник»." Chwe.org.ua, December 17, 2020.

Ukrainian Greek Catholic Church. "Lyst Blazhennishoho Svyatoslava z rekomendatsiyamy pro te, yak u chas pandemiyi Covid-19 sluzhyty strasni y paskhalni bohosluzhinnya | Лист Блаженнішого Святослава з рекомендаціями про те, як у час пандемії Covid19 служити страсні й пасхальні богослужіння." ugcc.ua, March 24, 2020. Accessed December 31, 2020. http://ugcc.ua/documents/list_blazhenn\%D1\%96shogo_svyatoslava _z_rekomendats\%D1\%96yami_pro_te_yak_u_chas_pandem\%D1\%96i_covid19_sluzhit i_strasn\%D1\%96_y_pashaln\%D1\%96_bogosluzh\%D1\%96nnya_89092.html.

"Vaktsyny, vyhotovleni na liniyi embrionalnykh klityn: mozhna chy ne mozhna vzhyvaty? | Вакцини, виготовлені на лінії ембріональних клітин: можна чи не можна вживати?" UCU School of Bioethics, March 6, 2019. Accessed December 31, 2020. http://bioethics.ucu.edu.ua/vaktsyny-vygotovleni-na-lyudskyh-biomaterialah-mozhna-chy -ne-mozhna-vzhyvaty.

YelENSKYY, ViKTOR | Єленський, Віктор. "Karantyn ne ye obmezhennyam relihiynykh svobod | Карантин не є обмеженням релігійних свобод." RISU, April 18, 2020. Accessed December 31, 2020. http://risu.org.ua/ua/index/all_news/state/church state_relations/79807.

"Yepyskopy UGKTS ta RKTS zaklykaly vladu ne zakryvaty khramy ta efektyvno vykorystaty koshty na podolannya pandemiyi | Спископи УГКЦ та РКЦ закликали владу не закривати храми та ефективно використати кошти на подолання пандемії.” RISU, December 9, 2020. Accessed December 31, 2020. http://risu.ua/yepiskopi-ugkc-ta-rkczaklikali-vladu-ne-zakrivati-hrami-ta-efektivno-vikoristati-koshti-na-podolannyapandemiyi_n114172.

ZhuKAlyuK, Mykola, and Viktoriya LyUBASHChENKo. Istoriya Tserkvi khristian Adventistov sedmogo dnya v Ukraine. Kyiv: Dzherelo zhyttya, 2003 | Жукалюк, Микола, Вікторія Любащенко. История Церкви христиан Адвентистов седьмого дня в Украине. Київ: Джерело життя. 2003.

"Zvernennya rektoratu z pryvodu pandemiyi COVID-19 | Звернення ректорату з приводу пандемії COVID-19." Ukrainian Catholic University (Rector's address, December 8, 2020). Accessed December 31, 2020. http://ucu.edu.ua/news/zvernennya-rektoratu-zpryvodu-pandemiyi-covid- 19 . 


\title{
HEALTH ISSUES IN THE GUIDELINES OF CHRISTIAN CHURCHES \\ IN THE CONTEXT OF THE COVID-19 PANDEMIC: TRADITIONS AND INNOVATIONS
}

\begin{abstract}
Sum mary
The article examines the guidelines of Christian Churches on human health problems in the situation of the COVID-19 pandemic. Attention is focused on those Churches that operate in Ukraine and the countries of the Euro-Atlantic circle: the Roman Catholic Church, the Ukrainian Greek Catholic Church, Orthodox and Protestant Churches. The documents and practical actions of these Churches, as well as reasoning of their representatives related to this topic are analyzed, in particular: organizing of church life in the conditions of COVID-19, peculiarities of the sacraments, an attitude towards vaccination and more. Orthodox approaches and innovations, which some clergy of different Churches consider incompatible with church doctrine, have been revealed. The innovations discussed concern various forms of online participation in liturgies and other types of church life, administrating of the sacraments, determining whether vaccination against coronavirus is moral, and so on. It is noted that right now and in the near future all Churches will have to clarify and supplement their guidelines according to the challenges of today's life. And the survival and authority of the Churches among contemporaries and future generations depend on the relevance of the corresponding evolution of church doctrines.
\end{abstract}

Keywords: Christian Churches; COVID-19 pandemic; church guidelines; church life online; orthodoxy; innovations.

\section{KWESTIE ZDROWOTNE W WYTYCZNYCH KOŚCIOŁÓW CHRZEŚCIJAŃSKICH W KONTEKŚCIE PANDEMII WIRUSA COVID-19: TRADYCJE I INNOWACJE}

\section{Streszczenie}

W artykule przeanalizowano wytyczne Kościołów chrześcijańskich dotyczące problemów zdrowia człowieka w sytuacji pandemii COVID-19. Uwagę skupiono na tych Kościołach, które działają na Ukrainie i w krajach obszaru euroatlantyckiego: na Kościele rzymskokatolickim, Ukraińskim Kościele Greckokatolickim, Kościołach prawosławnych i protestanckich. Przeanalizowano dokumenty i praktyczne działania tych Kościołów, a także argumentację ich przedstawicieli związaną z tą tematyką, a w szczególności: organizacja życia kościelnego w warunkach COVID-19, specyfika sakramentów, stosunek do szczepień i inne. Ukazane zostały ortodoksyjne podejścia i innowacje, uważane przez niektórych duchownych różnych Kościołów za niezgodne $\mathrm{z}$ doktryną Kościoła. Omawiane innowacje dotyczą różnych form uczestnictwa online w liturgii i innych formach życia kościelnego, sprawowania sakramentów, oceny czy szczepienia przeciwko koronawirusowi są moralne itd. Stwierdza się, że już teraz i w najbliższej przyszłości wszystkie Kościoły będą musiały uściślić i uzupełnić swoje wytyczne zgodnie z wyzwaniami współczesności. A przetrwanie i autorytet Kościołów wśród współczesnych i przyszłych pokoleń zależy od trafności odpowiedniej ewolucji doktryn kościelnych.

Słowa kluczowe: Kościoły chrześcijańskie; pandemia COVID-19; wytyczne Kościoła; życie Kościoła online; ortodoksja; innowacje. 